\title{
Pajatoiminta ohjauksen ja oppimisen tehokeinona
}

\author{
JUKKA VEHVILÄINEN
}

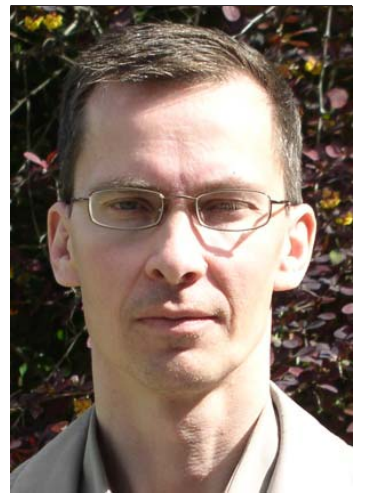

Työpajat ovat kuuluneet suomalaisen työvoima- ja koulutuspolitiikan järeimpiin keinoihin 1990-luvun puolivälistä lähtien. Niistä saadut kokemukset ovat yllättävän hyviä. Pajoihin on tultu negatiivisten koulukokemusten siivilöiminä. Siksi työpajoissa pyritään ja onnistutaankin tuottamaan myönteisiä oppimiskokemuksia sekä muuttamaan asenteita koulutusta kohtaan yleensäkin.
$\mathrm{K}_{\mathrm{o}}$

ulutuspoliittisessa keskustelussa puhutaan usein perusopetuksen ja toisen asteen välissä olevasta nivelvaiheesta. Tämä nivelvaihe on usein ymmärretty kahden koulutusmuodon välissä olevana taitekohtana, jossa nuori siirtyy koulutusjärjestelmässä yhden askeleen eteenpäin.

Tuoreimmissa asiantuntijaraporteissa nostetaan esille muun muassa työpajatoiminnan merkitys nuorten nivelvaiheproblematiikan kehittäjänä. Työpajat ovat kuuluneet suomalaisen työvoima- ja koulutuspolitiikan järeimpiin keinoihin 1990-luvun puolivälistä lähtien

Nykyisin ajatellaan kuitenkin yhä yleisemmin, että nivelvaihe tulisi määritellä pitempänä siirtymävaiheena, jonka kuluessa nuori alkaa suunnitella omia jatkokoulutusvalintojaan, selkeyttää ammatillisia toiveitaan ja hakeutuu jatko-koulutukseen.

Tämä laaja määritelmä (esim. Perusopetuksen ja toisen asteen koulutuksen...2005) kuvaa hyvin todellisuutta; toisille nuorille nivelvaihe on lyhyt ja helppo siirtymä - kuin luokka-asteelta toiselle hyppääminen - toisille nuorille nivelvaihe muodostuu monimutkaiseksi prosessiksi, johon sisältyy haeskelua, haparointia ja eri elämänsfääreillä poukkoilua. Nivelvaihetta eletään peruskoulun viimeisellä luokalla, mutta nivelvaihetta käydään läpi myös koulutuksen ulkopuolella, työssä tai työttömänä ollessa.
Koulutuksen asiantuntijat ovat korostaneet ohjauksen kehittämistä nivelvaiheen ongelmien ratkaisuna. Nivelvaiheen käsitteen laajeneminen on merkinnyt myös ohjauksen kohderyhmän ja ohjauksen toteuttamistapojen monipuolistumista. Nivelvaiheen opiskelijoihin kuuluvat peruskoulun päättäneiden ohella ammatillisen koulutuksen keskeyttäneet ja vaille ammatillista koulutusta jääneet nuoret.

\section{Työpajatoiminta koulutus- järjestelmän paikkaajana}

Tuoreimmissa asiantuntijaraporteissa (emt.) nostetaan esille muun muassa työpajatoiminnan merkitys nuorten nivelvaiheproblematiikan kehittäjänä. Työpajat ovat kuuluneet suomalaisen työvoima- ja koulutuspolitiikan järeimpiin keinoihin 1990-luvun puolivälistä lähtien. Työpajoja on perustettu esimerkiksi ESR-rahoituksella ja niissä kehiteltyjä käytäntöjä on pyritty siirtämään myös osaksi perusopetusta.

Työpajat tarjoavat nuorille opinto- ja ammatinvalinnanohjausta toiminnallisissa ja yksilöllisissä ympäristöissä. Ohjauksen perinteisten käsitteiden kautta tulkittuna (kts. Numminen ym. $2002,43)$ työpajat voidaan mieltää ohjausympäristönä, jossa ohjaus syntyy erilaisten interventioiden ja toimijoiden yhteistyön kautta. Työpa- 
joilla tehdään erittäin paljon nimenomaan niitä asioita, jotka on mielletty ohjausjärjestelmän tavoitteiksi. Työpajoilla annetaan lähtökohtia ammatinvalintaan, käsitellään kasvatuksellisia ongelmia, ohjataan opinnoissa ja tutustutetaan nuoria työelämään (vrt. Numminen ym. 2002, 44).

Voidaan puhua myös erityisistä "pajamaisista" käytännöistä, jotka ovat toteutettavissa myös muualla kuin työpajoilla. Esimerkkinä voidaan mainita Opetushallituksen koordinoima ESRkokeiluprojekti: Innovatiiviset työpajat ammatillisissa oppilaitoksissa, jonka puitteissa on vuodesta 1999 lähtien kokeiltu pajamaisia käytäntöjä keskeyttämisvaarassa olevien opiskelijoiden tukemiseksi.

Innovatiivisia työpajoja on toteutettu vaihtelevilla projektikonseptioilla ammatillisissa oppilaitoksissa. Hyvin monessa projektissa on kuitenkin sovellettu jonkinlaisella variaatiolla seuraavankaltaista mallia. Opettajien ja perinteisen oppilashuoltohenkilöstön välissä on usein erityinen pajavastaava (erityisopettaja, nuorisotyöntekijä tms.), jonka vastuulle keskeyttämisvaarassa olevat opiskelijat kuuluvat. Tämä pajavastaava toimii opiskelijan luottohenkilönä ja on tiiviissä yhteistyössä oppilaitoksen osastojen kanssa. Opiskelijalle järjestetään mahdollisuuksia lisäopintoihin - esimerkiksi rästiin jääneiden opintojen suorittaminen tai tukiopetus itselle vaikeassa aineessa. Tarvittaessa opiskelija ohjataan opiskelemaan jotakin muuta alaa tai jopa toiseen oppilaitokseen. Työharjoittelu- ja työssäoppimistilaisuuksia käytetään yksilöllisen tarveharkinnan mukaan. Mikäli opiskelijan ongelmat ovat niin pahoja, että pajavastaava ei pysty niihin vaikuttamaan, opiskelija ohjataan joko oman oppilaitoksen asiantuntijoiden tai ulkopuolisen yhteistyöverkoston piiriin.

Voitaisiin ajatella niin, että nuorten myönteiset kokemukset pajoista ilmentävät samalla valtavirran koulutusjärjestelmän ongelmia; pajat tuntuvat täyttävän jotakin tarvetta, johon perinteiset ohjaus- ja koulutuspalvelut eivät ole pystyneet vastaamaan. Tästä syystä pajoja voi lähestyä kahdenlaisella ihmettelyllä: miksi nuoret ovat kokeneet pajatoiminnan tarpeelliseksi ja miksi suomalainen ohjaus- ja koulutusjärjestelmä ei pysty täyttämään kaikkien nuorten tarpeita.

Olen haastatellut eri tutkimuksia varten (esim. Vehviläinen 2001) työpajoilla ja ammatillisten oppilaitosten pajoilla olevia nuoria. Näiden nuorten koulukokemukset voidaan usein - muttei aina - tiivistää klassiseen määritelmään "kouluallergia" (Takala 1992). Kouluallergia on eräänlainen koulutuksenvastainen asennetihentymä, jossa koulutukseen suhtaudutaan varautuneen epäilevästi.

Tämän asennetihentymän merkkinä oli ensinnäkin se, että nuoret tuntuivat mieltävän pajat osaksi yhteiskunnallista palvelujärjestelmää tässä mielessä pajat niputetaan yhteen peruskoulujen, ammatillisten oppilaitosten, sosiaalitoimistojen ja poliisin kanssa. Pajat ovat kuitenkin sen lisäksi "jotakin muuta". Avainsana on se, että pajakokemukset ovat usein osoittautuneet $y$ llättävän hyviksi. Yllättyminen on merkki siitä, että nuoret ovat odottaneet pajajaksolta sellaisia kokemuksia, joihin he ovat tottuneet aikaisemmin vastaavanlaisissa tilanteissa. Pajoille on menty sellaisen odotushorisontin kautta, jossa pajajakson on ajateltu sisältävän luokkahuoneopetusta, tiukkailmeisiä viranomaisia ja ahkeraa suorittamista. Koulutusyhteiskunnassa koko elämänsä viettäneet nuoret eivät kovin helposti pääse eroon koulutusta kohtaan tuntemastaan epäluulosta.

\section{Kun pajakokemus yllättää}

Tähän tulkintaan yllättävän hyvistä pajakokemuksista voidaan pysähtyä hetkeksi. Se tuntuisi viittaavan siihen, että myönteisten pajakokemusten ensimmäinen vaihe on usein muurin tai epäilyksen murtaminen. Nuoren odotushorisontti ja koko ajattelurakenne on saatava myönteisemmäksi; nuorelle pyritään tuottamaan myönteisiä käsityksiä omasta koulutettavuudestaan sekä koulutuksesta yleensä. Ammattiin, koulutukseen ja tulevaisuuteen ohjaaminen alkaa menneisyyden haamujen poistamisella.

Työpajoilla oleville opiskelijoille näyttää usein olevan leimallista eräänlainen herkkyys arviointia ja ulkoapäin tulevia vaatimuksia kohtaan. Opiskelijoille on erittäin tärkeää, kuka heidän tekemisiään arvioi, millä tavalla arviointi tehdään ja kuinka suhtaudutaan mahdolliseen virhesuoritukseen. Pajanuoret kokevat motivoiviksi sellaiset oppimisympäristöt, joissa vaatimusten esittäjät koetaan erilaisiksi kuin aikaisemmin, vaatimukset esitetään erilaisessa ympäristössä kuin aikaisemmin ja vaatimuksiin saa vastata enemmän oman aikataulun mukaan.

Jos nuorella on paljon kokemuksia koulutuksellisesta epäonnistumisesta, uusien haasteiden vastaanottaminen ja oppiminen näyttäisivät edel- 
lyttävän ympäristöä, jossa virheen tekemistä ei pelätä etukäteen. Myös ammatinvalinnan suhteen näkyi sama teema: opiskelijat halusivat haeskella omaa ammattialaansa rauhassa lyhyiden tutustumisten kautta ja ulkoapäin tulevat tiukasti aikataulutetut vaatimukset koettiin stressaaviksi.

\section{Paljon henkilökemian varassa}

Toinen pajaopiskelijoita luonnehtiva seikka on kyvyttömyys suhtautua koulutukseen välineellisesti. Pajaopiskelijat antavat keskimääräistä enemmän merkitystä opettajan persoonallisille ominaisuuksille, opiskelijakavereiden mukavuudelle ja työpaikan kivalle ilmapiirille. Tämä on henkilökemioihin perustuvaa koulunkäyntistrategiaa, jossa koulussa viihtyminen ja pärjääminen saattaa kulminoitua siihen "tullaanko opettajan kanssa toimeen".

Tietenkin kysymys voi olla mukavuudenhalusta ja siitä lyhytjännitteisyydestä - nuoret eivät edelleenkään ole sisäistäneet koulutusjärjestelmän logiikkaa ja kaksoismerkitystä. Pajanuorten haastatteluiden perusteella on kuitenkin tehty myös tulkinta (kts. Vehviläinen 2001, 103), jossa mainitaan että mukavan ilmapiirin ja viihtymisen korostaminen liittyy myös edellä mainittuun arviointi- ja arvosteluherkkyyteen. Kun ympärillä on ihmisiä, joiden seurassa viihdytään ja jotka koetaan omiksi kavereiksi, opiskelijoilla on enemmän rohkeutta olla osaamaton oppija.

Esimerkiksi työharjoittelu- ja työssäoppimispaikoissa mukava työyhteisö lisää sosiaalista rohkeutta ja opiskelija on valmis kysymään tyhmiä kysymyksiä oppiakseen jotakin uutta. Tässä mielessä mukavat ilmapiirit ja toimivat henkilökemiat tasaavat opiskelijoiden eroja sosiaalisen rohkeuden ja oma-aloitteisuuden suhteen. Nämä ominaisuudet on puolestaan tunnistettu tärkeiksi esimerkiksi työssä oppimisessa ohjauksen, palautteen ja rehellisen arvioinnin saamisen kannalta.

Pajaoppimisen kannalta kuvio näyttäisi siis menevän näin: kun nuorten ja opettajien suhteet ovat kunnossa ja oppimisilmapiiri on myönteinen ja turvallinen, opiskelijoilla on enemmän rohkeutta tarttua uusiin haasteisiin. Kokeissa ja työtehtävissä epäonnistuminen ei merkitse sitä, että opiskelijaa ei arvostettaisi ihmisenä. Tämän perusteella voisi ajatella, että valtavirran koulutusjärjestelmä on jollakin tavalla yksiulotteinen; opinnoissa pärjääminen on ainoa tapa saada so- siaalista arvostusta ja itsetunnon kittiä. Jos opinnoissa ei pärjätä, niin opiskelijat hakeutuvat sellaisten inmisten pariin, joilta saa arvostusta muiden kriteerien perusteella. Tärkeintä on kasvojen säilyttäminen. Valtavirran koulutusjärjestelmässä kasvojen säilyttäminen tarkoittaa usein sitä, että opiskelija kiistää koulutuksen arvon tai hakeutuu sellaiseen ryhmään, jossa sosiaalista arvostusta saa muilla kriteereillä

Tämä näyttäisi olevan oleellista. Pajoilla nuoretkohtaavat ehkä ensimmäistä kertaa elämässään sellaisia inmisiä, jotka vaativat opettajamaisesti koulutusvalmiuksia, mutta antavat samalla mahdollisuuden kasvojen säilyttämiseen. Sosiaalinen arvostus ei ole yhden kortin varassa; nuoren on mahdollista olla yhtä aikaa huono opiskelija ja "hyvä tyyppi"

\section{Tärkeää saada tuntea olevansa "hyvä tyyppi"}

Pajaohjauksen ja oppimisen peruslähtökohta ja alku näyttäisi olevan se, että nuorelle tuotetaan käsitystä tämän hyvästä tyyppiydestä. Tokihan nuori sen saattaa tietää - läheisiltä inmisiltä on saattanut tulla vastaavaa itsetunnon kittiä. Pajoilla tuotetuilla myönteisillä tulkinnoilla on kuitenkin aivan erilainen kaikupohja: kehut ja kannustukset tulevat yhteiskunnan virallisen tahon edustajilta ja ne koskevat nimenomaan koulutukseen ja oppimiseen liittyviä asioita. Tältä pohjalta voidaan sitten suunnistaa eteenpäin. Nuorelle tuotetaan vaivihkaa käsitystä, että huolimatta koulutuksellisista epäonnistumisista jossain voisi olla hänellekin sopiva koulutuspaikka.

Pajanuorten haastattelujen perusteella voidaan väittää, että peruskoulu tuottaa usein kokemusta julkisesta epäonnistumisesta. Perinteiset luokkahuoneet ja pedagogiset käytännöt - esimerkiksi vastaaminen muun luokan kuunnellessa - osoittavat kaikille yksittäisen oppilaan osaamisen tason. Yksilölliseen opetukseen perustuvissa pajakäytännöissä tämä julkinen elementti on vähemmän keskeinen; sekä onnistuminen että epäonnistuminen ovat enemmän yksityisiä kokemuksia. Haaste on tietenkin siinä, kuinka myönteinen yksityinen kokemus käännetään julkiseksi onnistumiseksi.

Koulutuksellinen epäonnistuminen vaikuttaa nuoren käsityksiin omasta itsestään, tämän ohella epäonnistuminen ja koulutuksen ulkopuolelle jääminen tuottaa myös sosiaalista diskvalifi- 
kaatiota, jossa nuoreen kohdistetaan epäilyksiä yleisestä yhteiskunnallisesta kelpoisuudesta. Tästä syystä yksityiset kokemukset osaamisesta ja pärjäämisestä eivät sellaisenaan riitä; vahvistunut koulutusidentiteetti vaatii tuekseen myös muiden antamia arvioita.

Yksilöllisen onnistumisen ja julkisen arvioinnin vuorovaikutus näkyy erityisen hyvin sellaisissa projekteissa, joissa nuoret siirtyvät perusopetuksesta pajalle ja pajalta takaisin perusopetukseen. Lähtötilanteessa pajaopettajien ja muun oppilaitoksen kitkatekijät tiivistyvät usein erilaiseen tulkintaan opiskelijasta. Pajalla ajatellaan: osaa se, mutta muussa oppilaitoksessa; ei se osaa. Parhaimmat ja pysyvimpiin muutoksiin johtavat pajakäytännöt perustuvat tulkintojen muuttamiseen. Esimerkiksi omissa haastatteluissani törmäsin kahteen erilaiseen ja eri tasolla kulkevaan tilanteeseen, joissa molemmissa on kuitenkin sama teema: alkuvaiheen negatiivinen tulkinta muuttuu myönteiseksi, ongelmainen opiskelija tulkitaankin erilaiseksi oppijaksi.

Ensimmäinen tapaus on hyvin tyypillinen. Opiskelija, joka on pärjäämätön teoriaopiskelussa ja suorastaan nukkuu koulussa menee työharjoitteluun ja kiittävää palautetta työnantajalta. (vaihtuva tulkinta: se olikin työnkautta oppiva nuori). Toinen tapaus on ulkonäöltä luotaantyöntävä nuori (punkkari), johon pajanvetäjä rohkeni tutustua ja huomasi, että "ruman ulkokuoren alla" olikin hyviä ajatuksia. Kun tutustumisen kynnys oli ylitetty, paljastui, että nuorella oli myös erikoisia kykyjä ja omaa lahjakkuutta. Ensimmäisessä tapauksessa muutettiin opiskelutapaa ja toisessa ammattialaa.

\section{Pajamaisten käytäntöjen opetus?}

Työpajatoiminta eri muodoissaan on ollut 1990luvun puolivälistä lähtien olennainen osa suomalaista koulutus- ja työvoimapolitiikkaa. Pajatoiminnan kokemukset näyttäisivät opettaneen esimerkiksi sen, että moni nuori tarvitsee nivelvaiheessa kokonaisvaltaista toimintaa, jossa ohjaus, oppiminen, työnteko, itsetunnon parantaminen ja elämänhallinnan tukeminen liittyvät saumattomastiyhteen.

Tuoreimmassa asiantuntijaraportissa (Perusopetuksen ja toisen asteen koulutuksen...2005) pajat nostetaan esille yhtenä toiminnallisena mallina, mutta pajojen opetuksen voi nähdä myös siinä, että nuorten tunnustetaan usein tarvitse- van lisäaikaa nivelvaiheen siirtymässä. Ammatillisiin opintoihin tulee voida valmistautua kauemmin ja yksilöllisemmin; perusopetuksen lisäopetuksen kehittäminen ja toiminnallistaminen sekä ammatillisiin opintoihin suunnitellut orientoivat opintojaksot ovat eräitä signaaleja tästä ajatuksellisesta muutoksesta.

Oppilaitostasolla pajamaisten käytäntöjen oppia haetaan ns. hyvien käytäntöjen vakiinnuttamisen kautta. Projekti-ja hanketoiminta jatkuu edelleen, esimerkiksi Opetushallituksen koordinoimat ESR-työpajahankkeet jatkavat toimintaansa ainakin rakennerahastokauden ajan eli vuoden 2006 loppuun asti. Keskeisimmäksi haasteeksi on kuitenkin jo pitkään koettu se, missä määrin projekti- ja hankeinnovaatiot on mahdollista vakiinnuttaa osaksi perustoimintoja; projektitoiminnassa ongelmana on kehittämistyön päällekkäisyys, käytäntöjen kontekstisidonnaisuus ja puutteellinen leviäminen (esim. Arnkil \& muut 2005).

\section{Lähteet}

Arnkil, T. \& Seikkula, J. \& Arnkil, R. (2005). Hyvien käytäntöjen tutkittavuudesta, siirrettävyydestä ja toistettavuudesta. Yhteiskuntapolitiikka 6 / 2005. Vol.70.

Numminen, U. \& Jankko, T. \& Lyra-Katz, A. \& Nyholm, N. \& Siniharju, M \& Svedlin, R. (2002). Opinto-ohjauksen tila 2002. Opetushallitus.

Perusopetuksen ja toisen asteen koulutuksen nivelvaiheen kehittämistyöryhmän muistio (2005). Opetusministeriön työryhmämuistioita ja selvityksiä 2005:33. Opetusministeriö.

Silvennoinen, H. \& Klas, K. (1996). Kestääkö koulutususko pitkittyvän työttömyyden? Kasvatus 1, 62-72.

Takala, M. (1992). 'Kouluallergia', yksilön ja yhteiskunnan ongelma. Acta Universitatis Tamperensis. Ser. A; vol. 335. Tampereen yliopisto.

Vehviläinen, J. (2001). Innolla ammattiin? Ammatillisten oppilaitosten innovatiiviset työpajat-ESR-projekti. Opetushallituksen moniste 21/2001. 